\title{
Plywood Industry by Using Eco-efficiency Approach and LIA- Wood Balance Sheet Program
}

\author{
Yulia Nurendah, E. Gumbira Said, A. Miftah Fauzi, Zahrial Coto, M. Romli, Hartrisari \\ STIE Kesatuan, Bogor, Bogor Agricultural University, Bogor, Indonesia \\ E-mail: lia_niceone@yahoo.com
}

\begin{abstract}
The general purposes of this study were to improve the efficiency of wood utilization and to create wood's value added for plywood industry. To achieve the above purposes a strategy for Agro forestry Industry should be develop based on eco-efficiency principles. The details of targets were: (1). to analyze critical factors in plywood industry management regarding to eco-efficiency implementation, (2) to analyze production technology that is used in plywood industry, and (3). to design a developing strategy of integrated plywood industry based on eco-efficiency principles. The result of this study show that the key factors for plywood management's policy was environmental awareness; material utilization; and international issues. The production technology of all plywood industry in Indonesia is relatively similar. They are using the machineries of the 80's and have the similar working procedures. The kinds of wood wastes generated from plywood industry were classified into log end, reject log end, green veneer waste, and others. The wood waste was calculated $49.52 \%$ released from $100 \%$ input log in plywood industry. There are three strategy of integrated plywood industry based on eco-efficiency, namely (1) selecting and managing of environmental impact, showing three kinds of waste which affect the environment (2) Improvement the plywood manufacturing technology, showing the new innovation technology or process control management and (3) Development of new product from wood waste. Wood waste can be used to produce block board, laminated board, handicraft, and others.
\end{abstract}

Keywords - Value Added; Eco-Efficiency; Wood Waste; Strategy; Plywood Industry.

\section{INTRODUCTION}

\section{A. Basic Thinking}

Forestry sector supported Indonesian economic development for several years, lead by forest's product utilization. As a prime commodity, export of plywood industry contributed a significant number for national income. Since the transitional regime of Indonesian Government- from the new order to reformation- the performance of forestry sector are decline.

The problems in forestry sector directly influence to wood industries, including the turmoil of economics. The factors are monetary crisis and wood supply.

There are only about $50 \%$ log that be utilized from cultivated volume of wood. There are able to conclude that the wood industry still inefficient in raw materials utilization.

In the frame of the increasing wood industry performace, the forest as a major strength of wood industry should be managed due to the potenciality, resources and forest area. In the other side, there are must consider about sustainability of forest, ecosystem, and environmental.
There are need more supporting tools of policy and regulatory aspects that be complied consistenly.

Implementing eco-efficiency including integrated economic development, more efficient resources utilization, and pollution prevention are significant as sustainability. Eco-efficiency also as one significant aspect in business strategy development for industry.

Implementing eco-efficiency including integrated economic development, more efficient resources utilization, and pollution prevention are significant as sustainability. Eco-efficiency also as one significant aspect in business strategy development for industry.

The plywood industry shall increase their raw materials utilization by the more ways; one of them is improving the machinery performance. The improvement machineries will be produced more high quality product, maximized in wood converting, and more spend in energy utilization. In the other side, waste utilization shall be taken maximized by using eco-efficiency approach. Waste utilization will contribute in value added increment environment, finance, and social.

\section{B. Purposes of Research}


The research generally designed to analyse the factors to formulated the management policy of plywood industry. The policy shall be subjected to eco-efficiency implementation due to efficient in raw materials consumption. The details of research goals descibes as follows :

1. Analysing the positioning of plywood industry and analysing the eco-efficiency implementation both technically and managemently.

2. Analysing the production technology that be implemented in plywood industry. The study explored the technology impelementation including wood waste potentian data both quantity and quality. The study analysed the innovation technology that be choosen in efficiency improvement for wood industry. One of output of this analysis is Wood Balance Sheet

3. Designing the strategy to improvement wood's value added by using eco-efficiency approach.

\section{Eco-Efficiency}

In the economic development, the balance between ecology, development, and social welfare is the major pillar in sustainable development (Gumbira-Sa'id, 1997). As a major basis of industrial contribution to sustainable development, eco-efficiency shall combine the economic growth by more efficient in resources utilization and pollution prevention.

The practical implementation eco-efficiency is analysis by using seven eco-efficiency criteria (DeSimone and Popoff, 1997) that is described as follows:

1. Pressing the intensity of materials consumption;

2. Pressing the intensity of energy utilization;

3. Pressing the toxic materials distribution;

4. Renewability

5. Maximizing the sustainable utilization of renewable resources

6. Product preservation;

7. Improvement service intensity of products.

The eco-efficiency analysis in management aspects is carry out by using nine elements of eco-efficiency. All of the elements that able to assure the success of eco-efficiency, according to DeSimone and Popof (1997) are described as follows:

1. Leadership,

2. Foresight,

3. Corporate Culture,

4. Management Tools,

5. Life Cycle Management,

6. Procurement

7. Production and Operations,

8. Marketing,

9. After sales Service and Disposal,

\section{Value Added}

Value added often be defined refer to economic view; therefore actually value added must be viewed from the other aspects. The definitions of value added in the expanse discussion in wood industry sectors, not limited only in money value, but also be taken form raw materials utilization, recovery rates, and wood species variability that be used. In the other side, the labor intense and business opportunity in Indonesia shall be classified as value added.

\section{RESEARCH METHODS AND ANALYSIS}

\section{A. Analyzing the Recent Condition of Indonesian Plywood Industries}

The recent condition of Indonesian Plywood Industries will be evaluated by using IFE-EFE Matrix. The positioning of a plywood industry will be known based on IFE-EFE Matrix.

\section{B. Analyzing the Eco-efficiency Implementation}

Analysing the eco-efficiency implementation be carried out by two steps in below :

1. Techical Eco-efficiency Analysis. The question in this steps developed based on DeSimone dan Popoff (1997) questioneries. The answer score of all criterion will be averaged. The implementing of eco-efficiency be stated if the average value of each citerium is $\leq 3$.

2. Management Eco-efficiency Analysis. The analysis be carried out to evaluate the maintenance, compliment, and efectivity of environmental management system. Management Eco-efficiency Analysis is carried out by using criterium decision plus version 3.0-package computer program.

\section{Analysing The Plywood Production Technology}

Analisys of the plywood production technology be carried out by using three steps as follows :

(1) Analysing the recent implementation of technology and production process of plywood industries in Indonesia;

(2) Analysis the waste treatement and the efforts of wood wastes minimization;

(3) Designing of the wood balance sheet.

\section{Implementation Strategy of Improvement Wood's Value Added through Eco-efficiency}

Formulating the strategy based on the result that be explored from the previous steps. The formula explain some possible alternatives for company's strategy.

\section{E. Decision Making by using Non Numeric Methods for Pair wise Fuzzy Group Decision Analysis.}

To strengthen the decision making for selecting alternative in wood wastes utilization will carried out by using non-numeric method for pair wise fuzzy group decision analysis $(\mathrm{N} 22 \mathrm{FG})$ technique. The N22FG technique finds the best-chosen alternative for wood waste utilization. 


\section{RESULT AND DISCUSSION}

\section{A. The Positioning of Plywood industries by using IFE-EFE} Matrix

The IFE-EFE matrix already posted the position of Indonesian plywood industry regarding to internal and external factors evaluation. The matrix be design refer to David (1997) as be shown in Fig. 1.

The position be drawn that Indonesian plywood industries have opportunity and strengthness to implementing eco-efficiency. The result can be interpreted that the industries able to develop both market and products.

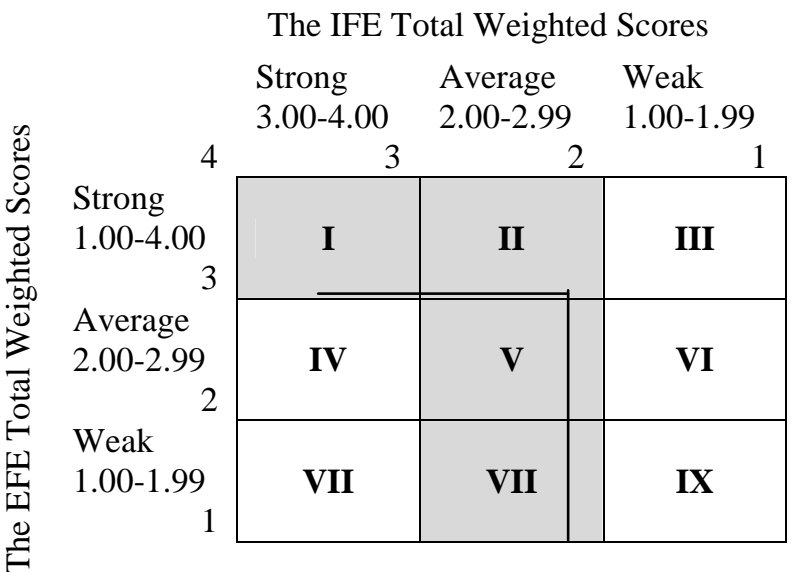

Fig. 1. Positioning of 13 plywood companies in Indonesia using InternalExternal Matrix

In this analysis, the positioning show that the plywood companies able to struggle and develop, but must taking more improvement i.e. production, quality, certified product, doing efficiency, and others.

The action be done to make assurance in quality and environmental friendly products. The quality and enfironmental friendly products will generate the company's image in International Market to increase market share.

\section{B. Result Analysis of Eco-efficiency Implementation}

1) Result of Technical Eco-efficiency Analysis: Table 1 show the result of probability value in eco-efficiency implementation for all of plywood industries that be evaluated. The result perform that overall eco-efficiency in plywood industries not yet clearly implementation. If the result continue to analyze in all of thirteen criteria then able to view the potential company, likes PT I which already implemented six of seven eco-efficiency criteria.

Therefore based on eco-efficiency implementation rule, there is no one of the criteria allow to neglect. There are able to conclude that all of 13 plywood industries in Indonesia not efficient yet

2) Result of Management Eco-efficiency Analysis: Management eco-efficiency analysis was carried out to analyse environment management condition in plywood industries. The result of analysis are combined of the respons from nine elements in questioneries both collected from plywood industries and expert. All of respondents data are manipulated by using criterium decision plus version 3.0. The final results show the priority scale series of ecoefficiency as shown in Table 2.

According to Table 2, the management technology element performs the highest value is 0.215 . There is able to interpret that according to respondent's companies the management technology shall take major consideration. The environmentally awareness can be used to defense in plywood industry competition scheme.

In the other hand, according to expert judgment, the leadership element must take major consideration, because all of activities and the need to regulatory compliment absolutely depend on the leader.

The two judgments both from expert and from industry in statistically have differentials about 0.99 or same as 1 . It means that there is no significance difference between two judgments. Environmental management element shall take major consideration, but it must be support by the leadership element.

Compilation between three factors are factories investigation, result analysis of technical eco-efficiency analysis, and management eco-efficiency analysis, are conclude that all of respondent's companies not efficient yet.

\section{Analysis of Plywood Production Technology}

1) Plywood Production Technology at Presents: The working procedure of plywood production for all industries in Indonesia are similar relatively, exluding log cutting, selection, and grading. The similarity of process be drawn from the machineries that be installed. Some industries still using Japanese machineries that be installed in 1980's.

Production process of plywood will release wastes that affect to environment. The wastes from every step in processing process divided into three forms are solid wastes, gas emission, and liquid wastes. Bark, small size scrap, sawing and sanding dust dominate the solid wastes.

2) Analysis of Innovation Technology on Plywood Production: Some technology innovation already implemented to improvement plywood processing efficiency, such as small spindle rotaries. The Machines can peel small size log-approximately $15 \mathrm{~cm}$ in diameter-and left the core about $6-8 \mathrm{~cm}$ in diameter.

The other innovation be developed to improve the sub materials use, especially for toxic materials substitution. The Phenolic resin still trying to substitute by natural latex in glue production. The formaldehyde-based glue will be replaced by isocyanates glue.

Indonesian Cleaner Industrial Program (ICIP, 1996), based on the survey that finance by USAid, already identified some chances to improve the environmental impact from Indonesian plywood industries. The chances are recomended to company and the implementation cost be financed by the respondent's company. 
TABLE I

PROBABILITY TO COMPLY THE ECO-EFFICIENCY REQUIREMENT FOR EACH RESPONDENT

\begin{tabular}{|c|c|c|c|c|c|c|c|}
\hline $\begin{array}{c}\text { Name of } \\
\text { Company }\end{array}$ & $\begin{array}{l}\text { Intensity } \\
\text { of Materials } \\
\text { Utilization }\end{array}$ & $\begin{array}{l}\text { Intensity of } \\
\text { Energy } \\
\text { Consumptio } \\
\text { ns }\end{array}$ & $\begin{array}{l}\text { Toxic } \\
\text { Materials } \\
\text { Distribution }\end{array}$ & Recycle & Resources & $\begin{array}{c}\text { Product } \\
\text { Preservation }\end{array}$ & Services \\
\hline PT. A & 3.27 & 3.00 & 3.00 & 2.91 & 3.39 & 2.54 & 3.00 \\
\hline PT. B & 3.27 & 3.00 & 3.00 & 2.91 & 3.39 & 2.54 & 3.00 \\
\hline PT. C & 3.27 & 3.00 & 3.00 & 2.91 & 3.39 & 2.54 & 3.00 \\
\hline PT. D & 3.45 & 3.00 & 2.90 & 3.27 & 3.43 & 2.54 & 3.00 \\
\hline PT. E & 3.36 & 2.45 & 2.25 & 3.00 & 3.00 & 2.90 & 2.91 \\
\hline PT. F & 3.36 & 2.45 & 2.25 & 3.00 & 3.00 & 2.90 & 2.91 \\
\hline PT. G & 3.36 & 2.45 & 2.25 & 3.00 & 3.00 & 2.90 & 2.91 \\
\hline PT. H & 3.36 & 2.45 & 2.25 & 3.00 & 3.00 & 2.90 & 2.91 \\
\hline PT. I & 3.36 & 2.45 & 2.25 & 3.00 & 3.00 & 2.90 & 2.91 \\
\hline PT. J & 2.73 & 3.18 & 3.22 & 3.55 & 3.65 & 3.67 & 4.45 \\
\hline PT. K & 2.64 & 3.09 & 2.91 & 2.82 & 3.48 & 3.85 & 3.91 \\
\hline PT. L & 3.18 & 3.36 & 2.84 & 3.18 & 3.22 & 2.52 & 2.18 \\
\hline PT. M & 3.27 & 3.00 & 2.30 & 2.82 & 2.58 & 2.66 & 3.09 \\
\hline
\end{tabular}

Source: Calculated data (2008)

Remarks: Eco-efficiency already implemented if the score $\leq 3$, and not yet implemented if the score $>3$

TABLE III

PRIORITY SCALE OF ECO-EFFICIENCY ELEMENTS

\begin{tabular}{|c|c|c|c|c|}
\hline Elements & Company & Expert & Deviation $\left(\mathrm{d}_{1}\right)$ & $\mathrm{D}_{1}^{2}$ \\
\hline Technology Management & 0,215 & 0,139 & 0,076 & 0,005776 \\
\hline Leadership & 0,157 & $\mathbf{0 , 1 8 9}$ & $-0,032$ & 0,001024 \\
\hline Marketing & 0,141 & 0,141 & 0 & 0 \\
\hline Operation and Production & 0,122 & 0,138 & $-0,016$ & 0,000256 \\
\hline Procurement & 0,104 & 0,076 & 0,028 & 0,000784 \\
\hline Foresight & 0,080 & 0,065 & 0,015 & 0,000225 \\
\hline Corporate Culture & 0,061 & 0,067 & $-0,006$ & 0,000036 \\
\hline After Sales Service & 0,061 & 0,068 & $-0,007$ & 0,000049 \\
\hline Life Cycle Management & 0,059 & 0,117 & $-0,058$ & 0,003364 \\
\hline Total Value & 1 & 1 & & 0,011514 \\
\hline \multicolumn{5}{|c|}{$\begin{array}{l}\mathrm{R}_{\mathrm{s}}=1-\left[\left(6 \times \sum \mathrm{d}^{2}\right) /(\mathrm{n} \times(\mathrm{n}-1))\right] \\
\mathrm{R}_{\mathrm{s}}=1-[(6 \times 0,011514) /(9 \times(9-1))] \\
\mathrm{R}_{\mathrm{s}}=1-[(6 \times 0,011514) /(9 \times 8)] \\
\mathrm{R}_{\mathrm{s}}=1-[(0,069084) /(9 \times 8)] \\
\mathrm{R}_{\mathrm{s}}=1-0,0009595=0,9990405=0,99\end{array}$} \\
\hline
\end{tabular}

The ICIP program including two steps are : (1). Monitoring the production and wood utilization in all of unit processing; (2) Identification and evaluating the potentiality and new possibility about wood wastes utilization.

3) Designing The Wood Balance Sheet: Wood balance sheet be designed based on the processing steps of plywood production. The processing steps be divided in to some unit operations. The simple scheme of plywood production and excess wastes are shown in Fig. 2.

The simulation result of the LIA-Wood Balance Sheet Program showed that the recovery rates of plywood production is $46.21 \%$ (log based), water vapour and gas emission about $4.04 \%$, compression loss $0.23 \%$, and wood wastes about $49.52 \%$. The major utilization of wood wastes are be used for Boiler's fuel.

In Generally, the final residues of wood wastes will be send to open burning. The open burning will tends to serious environmental impact. The direct impact of open burning is dirty looks.

\section{Analysis Result of Wood Wastes Utilization}

1) Result of Decision Making for Wood Wastes Utilization Alternative by Using Non Numeric Method for Pairwise Fuzzy Group Decision Analysis: Decision making to selecting alternative of wood wastes utilization be carried out by using non numeric method for pairwise fuzzy group decision analysis (N22FG). The final result is the best alternative of wood wastes utilization. The Criteria that be used in that selection as follows:

1. Degree of Interest regarding to company's policy in environmental aspects;

2. Costing;

3. Operation in wood waste utilization

4. Effectively of wood wastes utilization. 


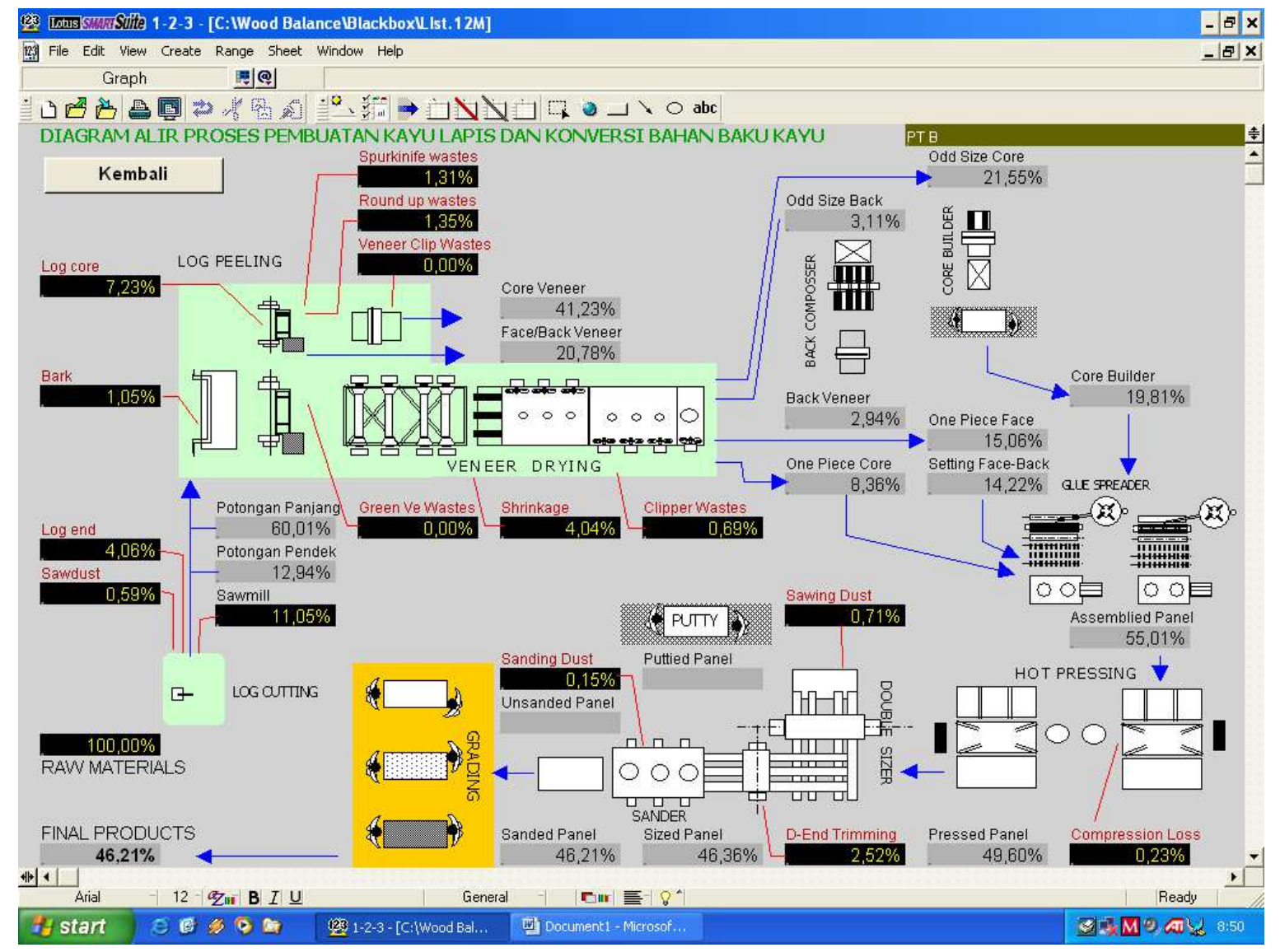

Fig. 2. Flow Diagram of plywood processing and the excess wastes in LIA-Wood Balance Sheet Program

Some alternatives of wood wastes utilization that be evaluate are:

1. Using only for fuels

2. Processing only for block board/packing materials

3. Processing until to woodcrafts

4. Dump to landfill.

Selecting the best criteria carried out based on the result of criteria aggregation and fill to given equations. However, if it found the value below AS then the lowest value will be chosen. The alternative result is posted in Table 3 .

There are being concluded that Alternative 3 is the best alternative. The alternative including processing chain from using wood wastes as boiler fuels, producing of block board/packing materials, and producing wood handy crafts

TABLE IIIII

ALTERNATIVE SOLUTIONS

\begin{tabular}{|l|l|l|}
\hline ALTERNATIVE & VALUE & REMARKS \\
\hline 1 & HD & \\
\hline 2 & HD & \\
\hline 3 & HP & Higest Value, Selected \\
\hline 4 & VHD & \\
\hline
\end{tabular}

\section{2) Wood wastes Utilization for Boiler Fuels}

There are about $12.36 \%$ of wood wastes be used for boiler fuels in plywood industry. Before deciding to use wood waste for boiler fuels, the wood wastes must be separate by the materials size. The final composition of wood wastes from plywood industry be explored in Table 4 .
About $30.31 \%$ of large size wood wastes be utilized as raw materials for down streams of wood processing. About $18.28 \%$ of large size wood wastes able to use for blockboard, 7.97\% as raw materials for Laminating Block, and about $4.06 \%$ are converted to handycrafts.

Comparative study by using non subsidized diesel for industry (selling price about Rp. 4.000,- per litre). Total costs of diesel fuels for Boiler approximately about Rp. 12.227,62 Billion/month. The diesel cost exclude the cost for ignition chambers modification, because all of boiler in Indonesian plywood industries be designed by using wood wastes. In contrast, the costs of boiler fuels from wood wastes is only Rp. 1,67 Billion/month. The value added from boiler fuels saving are Rp. 12.225,95/month.

\section{3) Wood wastes Utilization for Down Stream Industries}

Wood balance sheet analysis show that the converting of wood wastes to other product likes blockboard, laminating block, and handycraft do not effect to volume of wood wastes that be allocated for boiler fuels.

Wood working process actually is a primary forest industry likes plywood mill. But in the industrial planning of wood industry in Indonesia, the wood working industry usually be integrated by plywood mill.

Wood working industry can consume the wood wastes from plywood mill likes log core, log end, or the another size of $\log$ which not suitable for plywood. Production flow diagram of wood working and the excess of wood wastes show in Fig. 3. 
TABLE IVII

FINAL COMPOSITION OF WOOD WASTES IN PLYWOOD INDUSTRY

\begin{tabular}{|c|c|c|c|c|}
\hline & Details Wood Wastes Specification & Volume & $t^{U n i}$ & Percentages \\
\hline $\log$ & & 992.979,84 & M3 & $\mathbf{1 0 0 , 0 0}$ \\
\hline Plywood & & 458.876,59 & M3 & 46,21 \\
\hline \multirow[t]{10}{*}{ Boiler Fuels } & & $122.731,91$ & M3 & 12,36 \\
\hline & Saw dust & $5.814,61$ & M3 & 0,59 \\
\hline & Green Veneer Waste & $26.420,85$ & M3 & 2,66 \\
\hline & Dry Veneer Reject in Dryer & $6.843,82$ & M3 & 0,69 \\
\hline & Dry Veneer Wastes in Preparation & $64.651,24$ & M3 & 6,51 \\
\hline & Serbuk & $7.071,16$ & M3 & 0,71 \\
\hline & Plywood Edging (D-sized) & 0,00 & M3 & 0,00 \\
\hline & Sanding dust (Sander) & $1.503,94$ & M3 & 0,15 \\
\hline & Bark & $10.426,29$ & M3 & 1,05 \\
\hline & & $122.731,91$ & M3 & \\
\hline Compression Lost & & $2.332,90$ & M3 & $\mathbf{0 , 2 3}$ \\
\hline Gas \& Water Vapors & & $\mathbf{4 0 . 0 7 9 , 8 5}$ & M3 & 4,04 \\
\hline \multirow{7}{*}{ Final Wood wastes } & & $368.958,59$ & M3 & 30.31 \\
\hline & Log end/Sawmill & $109.695,44$ & M3 & 11,05 \\
\hline & Reject $\log$ end & $40.328,02$ & M3 & 4,06 \\
\hline & Log core & $71.835,83$ & M3 & 7,23 \\
\hline & Sanding dust & 0,00 & M3 & 0,00 \\
\hline & Plywood Edging (D-sized) & $25.061,11$ & M3 & 2,52 \\
\hline & Dry Veneer Wastes in Preparation & $54.097,83$ & M3 & 5,45 \\
\hline
\end{tabular}

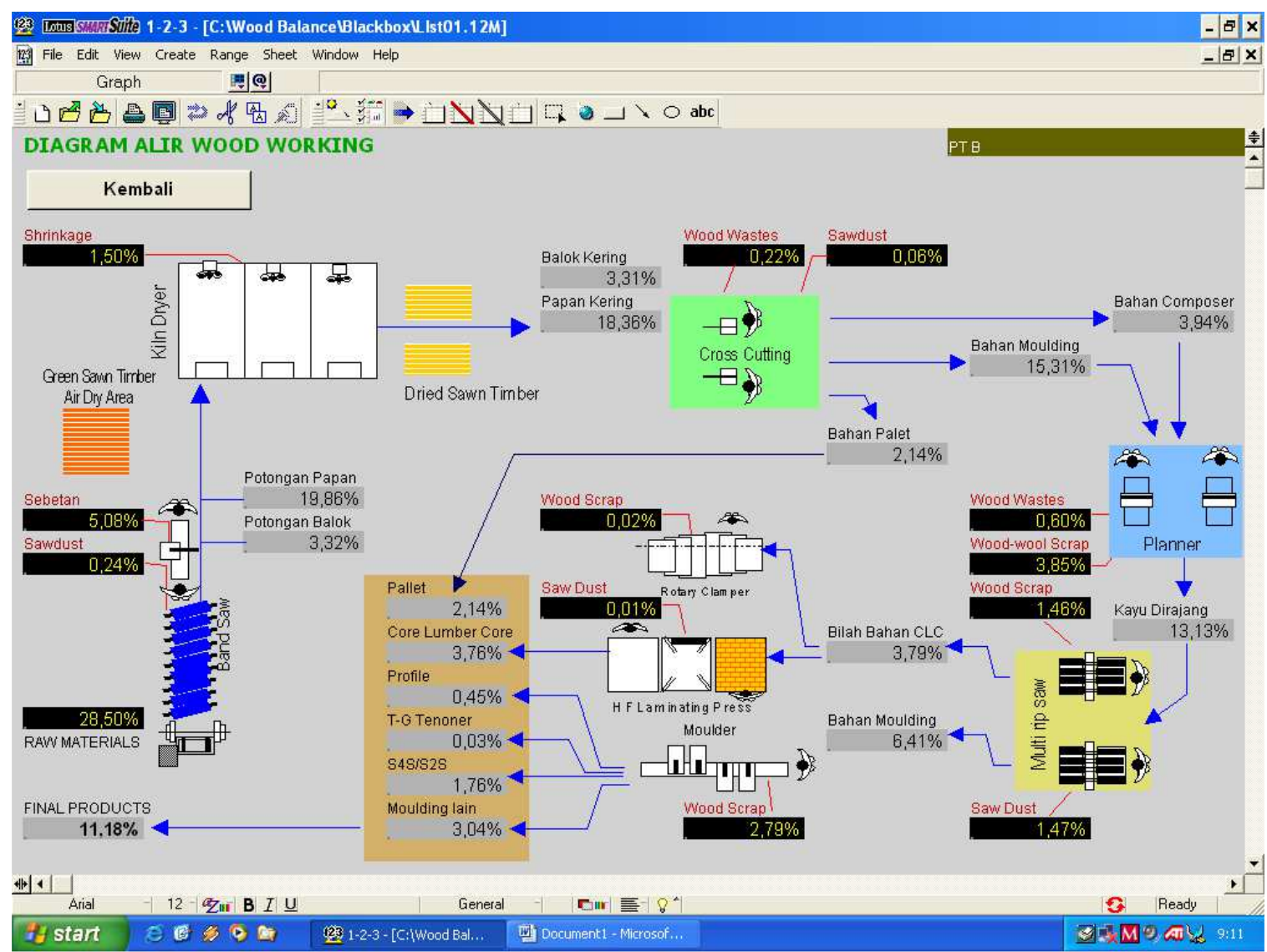

Fig. 3. Flow diagram of woodworking and the allocation of wood wastes

The recovery rates of wood working about $11.08 \%$, calculated based on raw log input in plywood mill. The wood wastes that reallocated as raw materials for down stream industry are $9.34 \%$.

The typical down stream industry from wood working is handycraft. The industry can use the small piece of wood for raw materials. The handycraft industry usually using more labour than machieries. Handy craft may yield about $6.93 \%$ from total $\log$ from Ply mill input. The final wastes from handy craft production are $0.92 \%$ and the others wood will be utilized as boiler fuels. Illustrate the flow diagram on handy craft processing on Fig. 4. 


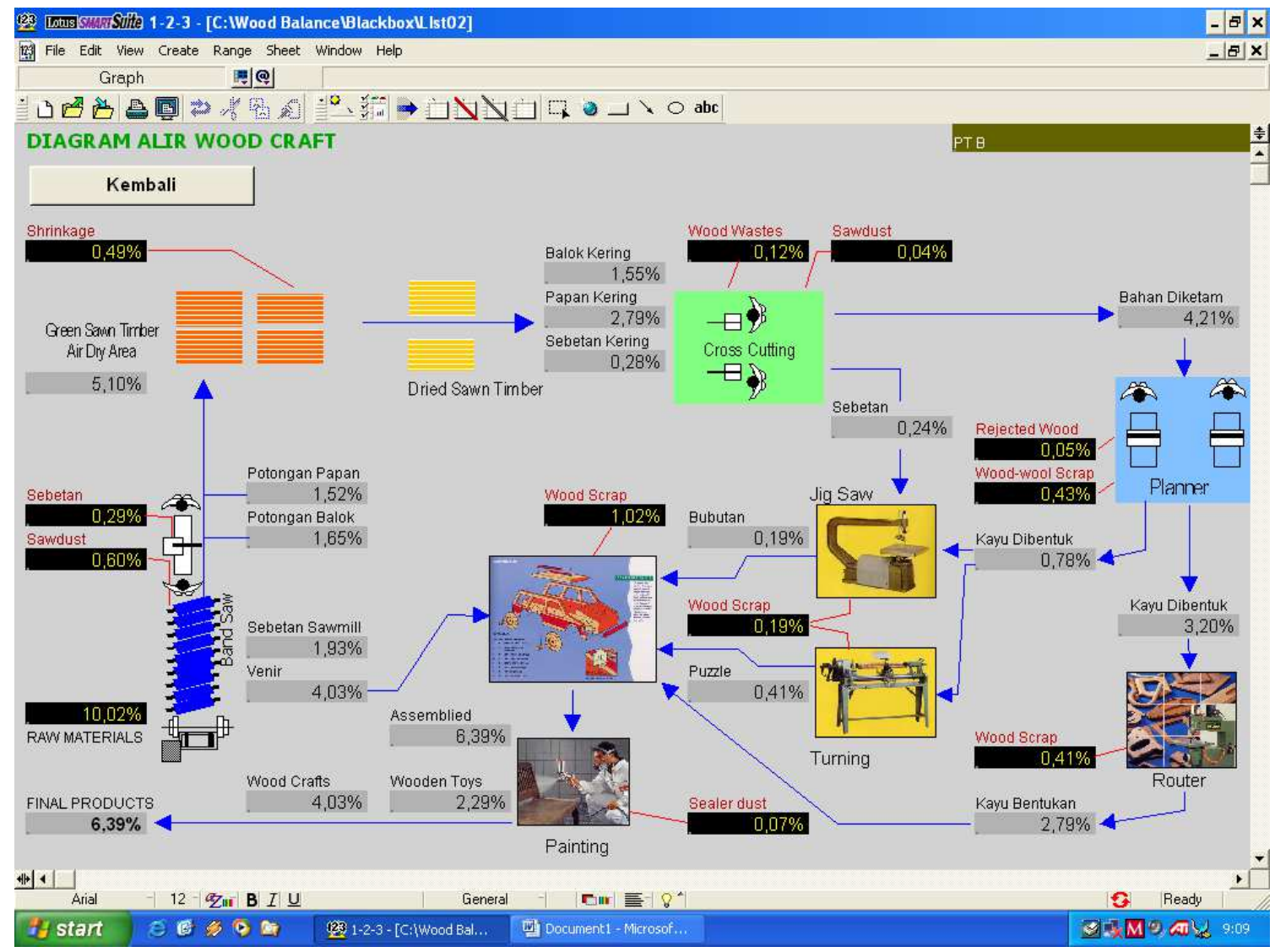

Fig. 4. Flow diagram of handy craft production and the waste distribution

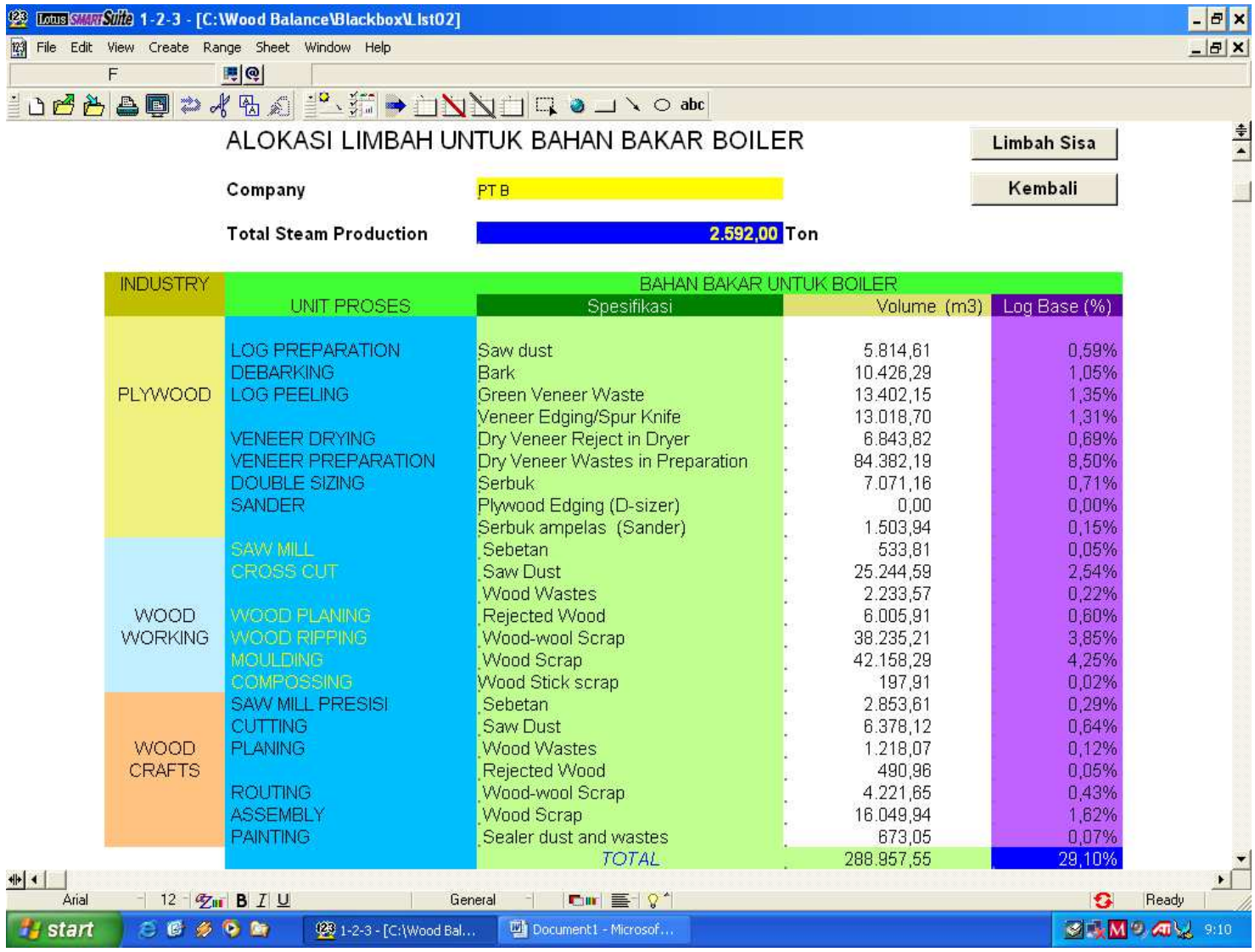

Fig. 5. Wood wastes allocation for boiler fuels, combination from integrated primary and down stream wood industries 
Finally, the total wood wastes that be utilized for boiler fuels from primary to down stream wood industries can be calculated precisely. The final calculation of wood wastes that allocated for boiler fuels be listed in Fig. 5 .

\section{IV.CONCLUSION}

Based on combination analysis between technical aspects of eco-efficiency and management aspects of eco-efficiency are concluded that all of plywood respondent's companies in Indonesia not implemented eco-efficiency yet. Therefore, whenever be deeped analysis by case, some of ecoefficiency criteria already be implemented by respondents. However, based on eco-efficiency implementation rule, the eco-efficiency status only performed if all of criteria already fully implemented. The conclusion that none of respondent plywood companies in Indonesian implement eco-efficiency yet.

Strategy for improvement wood's value added in plywood industry can be done by four ways as follows:

1. Carry out the eco-efficiency to improve the product image, more efficient, and minimizing the wastes;

2. Using the new innovation processing technology, including technologies for reuse and recycle the wastes;

3. Improvement wood's value added through wood waste recovery. Recovery process will give more value added in economically, social, and environment.

4. Producing the environmental friendly side product by reusing wastes.

The survey be conclude that all of respondent's industries are relative similar in processing technology. The installed production's machineries draw the similarity. Implementing the innovation technology is begun from the early 1990.

In the frame of plywood quality improvement, Indonesian ply mill should review several manufacturing aspects regarding to eco-efficiency. The improvement priority for plywood is high-class quality.

Indonesian plywood should adopt the innovation technology to improve their capability. The financial side must be supported as a logical consequence to buy technologies that are more modern.

The important to do for Indonesian plywood industries is trying to reevaluate which one the several aspects of ecoefficiency that be carried out successfully. Eco-efficiency program must be done to improve wood's value added.

\section{REFERENCES}

[1] David,F.R. 1997. Strategic Management. Six Editions. Prentice Hall. New Jersey.

[2] DeSimone,L.D and F. Popoff. 1997. Eco-efficiency: The Business Link to Sustainable Development. The MIT Press. Cambridge Massachusetts. London.

[3] Dennis, Pascal. 1997. Qualities, Safety, and Environment: Synergy in the $21^{\text {st }}$ Century. ASQC Quality Press, Wisconsin.

[4] Effendi, 2000. Prospek Industri Kayu. Makalah disajikan pada Majalah Tropis No 3 Th II Maret. PT Alam Warta Tropis Jakarta.

[5] Gumbira-Sa'id,E. 2003. Paradigma Bisnis Berorientasi Pembangunan Berkelanjutan: Fokus Khusus Manajemen Ekoefisiensi. Makalah disajikan pada buku Visi Baru Kehidupan. Penerbit PPM.

[6] Hermawan.1999. Teknik dan Jaminan Mutu Produksi Kayu Lapis di Indonesia. Mutu Agung Lestari.
[7] Hermawan dan Marimin. 2001. Penetapan Status Ramah Lingkungan Bagi Kayu Lapis Indonesia Berdasarkan Pemeriksaan Daur Hidup-Standar ISO 14040:1997(E)-Menggunakan Sistem Pakar Berlogika Fuzzy. J. Standardisasi Vol.1-2001:Maret

[8] Indonesia Cleaner Industrial Production Program (ICIP). 1998. Kajian Produksi Bersih Pada Industri Kayu Lapis. Jakarta.

[9] Marimin, Umano et al . 1997. Non Numeric Method for Fuzzy Group Decision Analysis. Journal of Intelligent and Fuzzy System. Vol. 5 257-269. IOS Press. Japan

[10] Marshall, R. 2001. Sustainable Development - from theory towards practice. The Environmentalist: 4 pp. 20-22.

[11] Nurendah, Y. 1998. Kajian Pemanfaatan Limbah Kayu Melalui Teknologi Bebas Limbah di PT Internasional Timber Corporation Indonesia. Tesis. Program Studi Magister Manajemen Agribisnis. Institut Pertanian Bogor.

[12] Uren, S. 1999. Environmental Supply Chain Management. Environmental Assessment. Volume 7. Issue 1 pp. 14-16.

[13] UNEP. 1991. Audit And Reduction Manual for Industrial Emissions And Wastes. UNEP IE/UNIDO, Vienna.

[14] Upton, C. and Stephen Bass. 1995. The Forest Certification Handbook. Earthscan Publication Ltd., Upsala. 